\title{
Study of Culture Teaching in English Teaching of Senior Middle Schools ${ }^{*}$
}

\author{
WANG Wei \\ Quzhou University, Quzhou, China
}

\begin{abstract}
Language is a part of culture and the carrier of the culture. Foreign language study is not only the process of learning a language but also the process of taking the language as a means of information transmission to comprehend culture. With the implementation of the New Curriculum Standard (2017) in senior English, the notions of cultural awareness and culture instruction are being accepted and carried out in EFL (English as Foreign Language) classroom by English teachers. This paper tries to analyze the relationship between language and culture, the contents and goals in teaching foreign language and culture, the significance of teaching culture in foreign language education. This paper concludes with recommendations for improving culture teaching: Learning a foreign language is inseparable from learning its culture; The knowledge of culture differences may help students to make less pragmatic errors and become proficient in cross-cultural communication; Great efforts should also be paid to the development of the student's cross-cultural awareness, and then the quality of English teaching could be really improved.
\end{abstract}

Keywords: culture teaching, English teaching, senior middle school (SMS)

\section{Introduction}

Foreign language learning is comprised of several components, including competence, communicative competence, language proficiency, as well as a change in attitudes towards one's own or another culture. Cultural competence, known as the knowledge of the conventions, customs, beliefs, and system of meaning of another country, is disputably an integral part of foreign language learning, and many teachers have seen it as their goal to incorporate the teaching of culture into the foreign language curriculum.

In order to improve our understanding of culture within the context of foreign language, firstly, we need to examine clearly how culture has been treated in foreign language education, especially in the teaching of English as foreign language. This paper will attempt to analyze the new situations in culture teaching under the implementation of New Curriculum Standard (2017) and will mention some recent and innovative methods or practices related to the teaching of language and culture. Furthermore, we will elaborate the culture teaching is necessary in a foreign language classroom for effective language learning.

Different cultures have different norms, values, and schema. Dunnett, Dubin, and Lezberg (1986) have

\footnotetext{
* This paper is sponsored by key subjects fund of Quzhou University. WANG Wei, master, lecturer, College of Foreign Languages, Quzhou University, Quzhou, China.
} 
made the following observation:

(1) Language cannot be translated word for word.

(2) The tone of a speaker's voice carries meaning.

(3) Each language or culture employs gestures, body movements that convey meanings.

(4) We also understand that different languages use different grammatical elements for describing all parts of the physical world.

(5) All cultures have taboo topics.

(6) In personal relationships, the term for addressing people varies considerably among languages.

All these differences bring foreign language learners a lot of difficulties and cause conflicts among different cultural groups in intercultural communication. As a result, culture instruction has become a very important topic in foreign language teaching.

\section{Culture and Language}

Culture is an extremely complex concept and an enormous subject. It almost embraces everything in every field. How complex it is, it can be roughly classified into three categories: (1) material culture which refers to all the products of manufacture, (2) institutional culture which refers to social system, religious system, ritual system, education system, and kinship system, etc., and (3) mental culture which refers to people's mentalities and behaviors, their beliefs, perceptions, concept of value, thought pattern, etc.

\section{Relation Between Language and Culture}

Language is the symbolic system of human communication, when it is used in the communication, it is bound up with culture in a multiple and complex way. Language expresses, embodies, and symbolizes cultural reality (Kramsch, 1993). Some social scientists consider it the keystone of culture. Without language, they maintain culture would not be possible. On the other hand, language is influenced and shaped by culture: It reflects culture. Culture is an integral part of language. Language and culture are closely related, each influencing and shaping the other. Numerous authors (see for example Byram \& Taylor, 1991; Byram \& Fleming, 1998; Kramsch, 1993) have highlighted the impossibility of teaching English without teaching culture. Whether culture is consciously or unconsciously part of the teachers' pedagogic aim, the transmission of culture is unavoidable. The content of what we teach will always be in some way linked to culture, every lesson is about something and that something is cultural.

\section{Goals of Culture Teaching}

Usually, there are mainly two goals in EFL (English as Foreign Language). One is to help learners acquire and grasp some essential reading English newspapers, magazines, academic books, but also for writing essays, papers, and academic reports in English. That is to formulate a solid foundation of skills, language, and attitude required for further study, work, and leisure. The other is to help learners remove their language obstacles, get to know another culture, enhance their communication competence, improve their English knowledge, and draw conscious attention to the similarities and differences from the learners' first language.

According to seelye's "seven goals of culture instruction” (1987), the teaching of culture has the following goals: 
(1) To help students to develop an understanding of the fact that all people exhibit culturally conditioned behaviors.

(2) To help students to develop an understanding that social variables such as age, sex, social class, and place of residence influence the ways in which people speak and behave.

(3) To help students to become more aware of conventional behavior in common situations in the target culture.

(4) To help students to increase their awareness of the cultural connotations of words and phrases in the target language.

(5) To help students to develop the ability to evaluate and refine generalizations about the target culture, in terms of supporting evidence.

(6) To help students to develop the necessary skills to locate and organize information about the target language.

(7) To stimulate student's intellectual curiosity about the target culture, and to encourage empathy toward its people.

Basically language teaching is related to bringing a target culture to learners, or, language learning is related to learning about another culture and an ability to communicate with native speakers. Therefore, language teaching and culture teaching should be integrated.

\section{Discussion Focus on Culture Teaching in SMS (Senior Middle School)}

\section{The Necessity of Culture Teaching in SMS}

The new syllabus for SMS. The new syllabus points out the close relationship between language and culture. As we all know, language is an import carrier of culture. One often reads in teacher's guidelines that language teaching consists of teaching the four skills plus culture.

The books of SEFC (Senior English Book for China) are based on a communication syllabus, which in contrast with a grammatical syllabus aims to make learners communicatively competent. It is also an analysis of the learners communicatively competent and an analysis of the learners' communicative needs.

The importance of culture instruction in senior English. In the learning of a foreign language, learners are not only faced with the target language but also with the target culture. Culture is a mental construct, a conceptual network that evolves within a group to provide a manageable organization of reality. It involves ideas, beliefs, customs, skills, arts, and so forth; and it fills definite biological and psychological needs and establishes for the individual a context of cognitive and affective behavior. It is bound inextricably to language (Arnold, 2002). It is important to teach culture in English class at least in the following two aspects:

(1) Teaching culture can avoid some breakdowns in intercultural communication and help students to understand and use English appropriately. Because of cultural differences, misunderstanding may arise frequently, even though the language used in communication is faultless. Just as Edward Sapir said,

Language has a setting. The people that speak it belong to a race (or a number of races), that is, to a group which is set off by physical characteristics from other groups. Again, language does not exist apart from culture, that is, from the socially inherited assemblage of practices and beliefs that determines the texture of our lives. (Sapir, 1961, pp. 221-231) 
(2) Teaching culture can coordinate the relationship between linguistic competence and social competence. The syllabus of Senior English demonstrates that the purpose of English teaching is to help students acquire communicative competence. Communicative competence includes two aspects: linguistic competence (competence of listening, speaking, reading, and writing) and social competence. A student with linguistic competence may speak the language correctly, but without social competence, he may not use the language at an appropriate time or in an appropriate place. That is, what he says may lead into culture shock. Learners who only have linguistic competence but lack social competence may bring about embarrassment in their conversation with foreigners.

In a word, if we want to develop students' communication competence to meet the requirement of the society and economy, we should try every means to integrate culture instruction with language teaching in every class from right now on.

The problems in EFL teaching. Rigid learning motives of learners for exams, but not ability. We are always advocating quality-oriented education, but for most Chinese students, English is only a "subject" and also a "major subject". The senior middle school students learn it, because it will be tested in the college entrance examination, and it is a necessary part of obtaining a good mark. Under these circumstances, learners only see English learning as a learning process; a way of attaining some goal; the stepping-stone to enter a university. After the exam, the stepping-stone will be thrown away randomly.

Traditional teaching aims and limitations of teachers. For many language teachers, language is a kind of knowledge and language learning is to recite pattern drills and memorize new words. When they give a test, they only test on what is learned within textbooks. They even encourage their students to memorize from the dictionary. This kind of practice only makes English learners know exactly how to use what they have learned.

One of the reasons for this is language teachers' traditional aim-for exams. They don't want to go beyond the textbook. Culture teaching requires teachers to have a wide knowledge of culture. But most teachers are not qualified for teaching culture. Some teachers regard English teaching only as a job, a way of making a living. Further, due to the limit of many conditions, most senior middle school English teachers who teach English throughout their lives never have been abroad and have never talked to native speakers face to face.

As a result, most of our English teachers in senior middle schools are lacking in bi-cultural ability. Thus, they can't transmit the culture teaching into the English teaching very well.

Neglecting the training of cross-cultural communicative ability. Traditional English teaching overemphasizes the training of pure language competence, insisting on fostering basic skills and techniques of listening, speaking, reading, writing, and translating. Methods such as "pattern drills teaching” pay more attention to language teaching, but neglect the social significance of language form, which makes language teaching seriously divorced from culture teaching. Even though students have the ability of expressing English, they don't really understand and grasp English and are lacking in the ability to use English in the right situation .

\section{Ways of Improving Culture Teaching}

Improving assessment of culture learning. To further strengthen the integration of culture with language learning, the assessment of culture learning is a very necessary and important part of the whole project of culture instruction. Otherwise, culture learning might probably be regarded again as something of secondary importance. English teachers should first consciously integrate culture instruction with language teaching in class and they 
should also help students to realize that cultural knowledge is one of the basic goals of the course, and that they will be tested over cultural information presented. As for what to be taught and what to be tested, we will discuss in the following. Byram (1994) and Cain (1995), in the discussion of what to test and how to test, described the following items:

(1) The "content" to be tested: knowledge, attitudes, and behavioral skill with respect to the non-verbal dimensions of social exchange;

(2) The ability to investigate: These should also be tested since we have focused on ethnographic techniques;

(3) The techniques for testing: oral and or written assessment, using role-play, using the essay;

(4) The criteria for assessment and the determination of levels of competence.

In short, a cultural test is very important for ensuring systematic and consistent culture instruction. Therefore, English teachers designing exam papers should bear in mind the great instructive effect of test papers on culture teaching and learning and should design a certain number of culture test questions in exam papers.

Measures for teacher development. To improve teaching standard and become a qualified English teacher, a SMS English teacher should firstly master relevant disciplines such as Linguistics, Psycholinguistics, Sociolinguistics, Psychology, Pedagogy, Second Language Acquisition and Language Teaching. Secondly, an English teacher should attend pre-service training that integrates academic subject studies with pedagogical studies and teaching practice. Thirdly, an English teacher should actively take part in programs allowing teachers to study and work abroad for some time, which will contribute a great deal to the high level of language proficiency among foreign language teachers. And to do this, the government should allocate more funds to improve English teaching environment and increase the number of English teachers. Fourthly, reflective practice should be included in teacher education programs.

Teacher development activities may include:

(1) visiting colleagues' classes;

(2) reading academic journals and books;

(3) attending conferences, workshops;

(4) collaborating with other teachers in classroom research or other professional projects;

(5) joining in telecommunication networks.

Only when the notion of teacher development is widely accepted by English teachers and when they actively take part in the teacher development activities, can culture instruction be successful in Senior English.

Suggestions on integrating culture instruction with language teaching in EFL classrooms. While textbooks offer interesting cultural content and the culture objectives are explicitly prescribed in the Curriculum Standard, the teaching of culture and the development of intercultural competence depend in a large part on how textbooks are used in the classroom, that is, on the quality of interaction between students, texts, and teachers. Beyond textbooks, what is required is a methodology of cultural teaching.

For successful cultural teaching, we suggest following methods:

(1) Present reading materials concerning the target culture: In textbook teaching, special attention should be paid to teaching the culture of the English-speaking countries, such as British and American cultural background and customs so that students can gain more cultural information and perform appropriately according to different contexts. 
(2) Teach cultural differences: Teachers should directly address the similarities and peculiarities between the native culture and the target culture. This can be done through the comparison of the two cultures.

(3) Provide opportunities for students to use the language in situational conversations: While systematically introducing the communicative cultural knowledge, teachers should also let students play a real-life role and practice their everyday language use according to the varied situations.

(4) Encourage students to read as much original materials as possible: To truly master the language, students and teachers should also learn the proverbs, idioms, and allusions of English, and even read the Bible, as they are the quintessence of the English language and have a great influence on the language.

(5) Organize discussions on different cultural aspects: These can be informal, unstructured cultural discussions or structured, hypotheses-testing discussions concerning a specific cultural aspect.

\section{Conclusion}

This paper analyzed the relationship between language and culture, the significance of culture teaching in EFL classroom, and give some recommendations for improving culture and etc. We know language is a part of culture, and the carrier of the culture. Learning a foreign language is inseparable from learning its culture; the language teaching and culture teaching should be integrated in EFL classroom. We suggest some ways to improve culture teaching.

Although it is not possible to discuss all aspects of culture teaching, it is hoped that one can realize that culture and language are intertwined and that culture teaching is an essential part of language education. Culture teaching allows learners to increase their knowledge and awareness of target language, people's way of life, cultural values, attitudes, and beliefs. Further research and investigation into this complicated aspect of foreign language teaching are needed to make culture teaching integrated with language teaching and help students develop communicative competence and cultivate cultural awareness to become a qualified 21st century workers and better serve the construction of our socialist country.

\section{References}

Arnold, J. (Ed.). (2002). Affect in language learning. Beijing: Foreign Language Teaching \& Research Press.

Byram, M., \& Taylor, S. (1991). Cultural studies and language learning. A research report. Clevedon: Multilingual Matters.

Byram, M., \& Fleming, M. (Eds.). (1998). Language learning in intercultural perspective: Approaches through drama and ethnography. Cambridge: Cambridge University Press.

Byram, M., \& Morgan, C. (1994). Teaching and learning: Language and culture. Bridgend: WBC Ltd.

Cain, A. (1995). French secondary school students’ perceptions of foreign culture. Language Learning Journal, l3, 48-52.

Dunnett, S., Dubin, F., \& Lezberg, A. (1986). English language teaching from an intercultural perspective. In J. Valdes (Ed.), Culture bound (pp. 148-161). Cambridge: Cambridge University Press.

Hinkel, E. (Ed.). (1999). Culture its second language teaching and learning. Cambridge: Cambridge University Press.

Kramsch, C. (1993). Context and culture in language teaching. Oxford: Oxford University Press.

Seelye, H. N. (1987). Teaching culture. Lincolnwood, Ill: National Textbook Company.

Sapir, E. (1961). Culture, language and personality. Berkeley: University of California Press. 